\section{The Students' Confession Toward Teacher Techniques in Teaching English}

\author{
1 Aswin Abbas \\ 2 Faiz Naufal Asrul
}

1 Akademi Ilmu Komputer Ternate, Indonesia

2 Universitas Cokroaminoto Palopo, Indonesia

\begin{abstract}
Confession contributes to the effectiveness and motivation both students and teachers. It invites the students' participation in determining the good technique for the best teacher. This research deals with students' confession toward teacher technique in teaching based on gender. The objective of the research is try to elaborate how is the students' confession on different gender, male and female in teaching. This research analyzed qualitatively where the subject takes from Senior High School 3 Palopo, 40 samples take which is confessing 10 male and 13 female teachers. After doing an interview, found that there are some confessions toward Gender teacher technique in teaching, they are both male and female get positive confessions, Male teachers get 36 confessions with good managing confessing (9) is the highest where correlated to the topic is a few or only 2 stdents confessed. Female teachers get 39 confessions with good managing confessing about 7 students assumed it and it is the highest. Furthermore, motivated confession only 2 confessing, and the last is female teachers get higher confession than male.
\end{abstract}

\section{Keywords \\ confession \\ gender \\ technique}

\section{Ethical Lingua}

Vol. 7, No. 2, 2020

ISSN 2355-3448 (Print)

ISSN 2540-9190 (Online)

Corresponding Email

Aswin Abbas

aswinabbas86@gmail.com

Article's History

Submitted 11 October 2020

Revised 14 October 2020

Accepted 14 October 2020

DOI

10.30605/25409190.224

Copyright (๑) 2020

The Author(s)

This article is licensed under CC BY-NC-SA 4.0 License 


\section{The Students' Confession Toward Teacher Techniques in Teaching English}

Language is a communication tool that used in daily life, not only Indonesian but also English contributes to our activities. It is no wonder all over the world to learn English. In Indonesia, English has been taught since elementary school to college, but so far has not confession the maximum results. English is a requirement of all people in a globalized world to communicate with the people in the world. English as well as foreign languages in the world.

In practice, teachers, male and female require to be able to use excellent techniques in the learning process in class. Harmer (2007) assumed that when the teaching and learning run in class, educators have to use good media and techniques related to the pupils competence, and that tools of teaching is crucial because it can provides completely result for the learner at the right class. Knowing linguistic and mental hypothesis, appearing thought of learner contrast, and understanding the guideline of child improvement and the characteristics of children at diverse stages of development will offer assistance get ready the teacher to make exercise that bring dialects and students successfuly. The question, is there any influence of gender in developing the students competence?

Gender has a big role in determining the students success in learning, in this case, difference gender has their own technique in teaching and of course, has value toward students confession. As the conclusion, contributes to the students performance in classroom even in mastering languages.

Wilkes (2010) covered confession could be a corner stone of the deliberatness life, not just a clearing out from the debris, that which bad or off-base, but realignment of what is nice in us, and an intention of making life better. It shows that confession is a base of someone begin a new kinds of life, expressing by the truth to gain better life. Like Wilkes, Shraddha (2013) said that confession is statement written or oral which is direct admission of suit. It could be stated that confession is a kind of statement that contains self-exculpatory matter which if true would negate the matter or offence.

In general, it is the message of having done something incorrect, whether on purpose or not. However, not all of confessions bears wrong activities, for example, a confession of love is often showed positive results both by the confessor and by the recipient, and it is also familiar in literature. Confession benefits the confessor. Wilkes (2010) defined confession as "a pillar of mental health" because of its ability to cure anxieties gathering with keeping secrets. From this definition, we could underline that confession could be a column of mental wellbeing. Confessors are more likely to confess when the expected benefits. People may attempts social confessions in arrange to remember sentiments of blame, feelings of guilt or to look for apologizing from a wronged party, but such confessions may also serve to make social bonds between the confessor and the person to whom they are communicate with, and probably prompt the listener to reply with confessions of their own. An individual may subsequently confess off-base doing to another individual as implies of creating a social bond, or of extracting complementary data from the others.

According to Lassiter (2004), there are two kinds of confession as follow: People confess for tell something and share some informations. They confess it of his/her own free will and tell 
it honestly when they are asked. People confess because they want to share their story explicitly or to correct a mistake. Usually without asked, they already confess it for their chest, giving a suggestion, and not happy with a certain situation and condition.

The point of confession would be given will focus on motivatiing, interisting in deliivering the topic, having good management in applying the technique, monitoring and stimulating the students, having good preparations, informing, using an appropriate technique and correlating to the topic. Slobogin (2007) also characterized confession as follow: Confession made to explain what was happened in his/her life and Confession made to explain what she or he desired in his/her life

Hirsch (2007) also said that sometimes confession no need a proof, but confessor have to promise or swear that she or he confess honestly. So the researcher tries to combine the explanation of the experts and make a conclusion that confessor revealed some informations about what was happened and desired honestly.

So, based of the explanations of the experts, the researcher argues that confession can also applied to evaluate the learning, include about the teacher technique in teaching because in the class activities, the things that want to be achieved is students are able to understand the lessons given by the teacher. so that, teachers can converse with students about the things that can help them in understanding the lessons, including teaching techniques. If the technique which used by teachers is difficult, they can meet the teacher to confess it and the students will be happy and no longer feel depressed or afraid if teachers want to receive feedback from the students,. Their spirit and mental in the face of the lessons will be more powerful, plus if teachers can really find a technique that allows them to understand the lesson.

Like media or others tool, technique also is a way used by the educators to coordinate the students activity toward the goal to be achieve. The teacher must choose an appropriate techniques with the material that teacher taught in order learning process become comfort. Selection technique should also interest so that the situation more fun and make students to be active in classroom (Halidasiah, 2016).

A technique is instrumentation - that which actually takes a big role in a classroom. It is a particular, sometimes named trick, strategy, or contrivance practiced to gain an immediate objective. Technique have to be consistent with a method, and thus in agreement with an approach as well. A technique shows typical diversity in applying a method in accordance with the background (setting), such as ability and habit of teachers, availability of school facilities and infrastructure, the ability and readiness of learners and so forth (Rianto, 2006).

An appropriate Techniques hang by a thread on the teacher, his skill, and how they compose class. Laksono (2014) mentioned that teachers could manage the class if they do the learning process in quiet and comfort class and also have a nice medias. Spesific problems could be overcome maximally by the use of variant techniques. For instance, in educating the distinction between the pronunciation of English /// and / $r /$ to view oriental students, teachers or instructors sometimes get results by requiring only imitation. If imitation does not work, another technique appear the use of a pencil in the mouth to prevent the student's tongue from touching the alveolar ridge, hence inhibiting the pronunciation of $/ \mathrm{I} /$. Another educators or the same teacher at another time might depend upon a drawing or chart of the vocal apparatus of human. 
Educators could master how to communicate well with pupils. The succesfull teaching begins when teachers stand in front of class. Whether they put theirselves as part of students' friend, or whether they keep a stranger, outside of their friendship. As a friend, of course teachers tend to develop a form of communication that is famous and happy. Starting with the habit of greeting them, asking for small things that make them feel attentive and appreciated by the teacher, to motivate them to keep trying to be more spirit in learning. They will feel more comfortable when listening, feel more attentive during the learning process, and feel more impressed to learn.

Lepiyanto (2011) said that teachers should to encourage students to find their own way in solving a problem and dictionary is a tool for students as a guideline for them to be confident with their own answers when working English task. When visitors view a class, they see mostly techniques. Teachers often feel uneasy in the presence of visitors, fearing a misinterpretation of their classes.

\section{Method}

This research applied qualitative method which aims to find out the students' confession on gender. The subject was 40 students of Senior High School 3. The instrument in this research was interview. The researcher used interview consists of 8 questions related to the students' confession. The researcher observed with using preliminary observation to know and make sure about the technique that teacher used. The researcher interviewed 40 students, choosed about the technique that teacher, male and female used.

According to Miles and Huberman (in Sugiyono, 2014), the data had been analyzed in qualitative way could be seperate into four ways, they are data collection, reduction, display and conclusion. The following is a diagram of the data analysis created by Miles and Huberman.

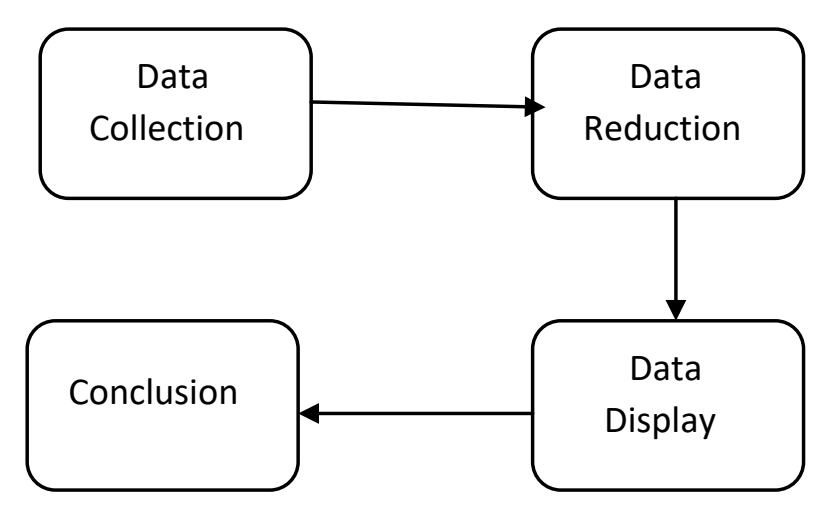

Figure I. Steps of Analyzing Data

\section{Results}

In this part, the researcher presents about finding or result of data analysis from interview. The data which had collected were analyzed to answer the research question that related to the students' confession of gender toward English teacher technique. Based on the interview to the students confessions can be seen in the following table. 
Table 1. List of students' confessions of their teacher

\begin{tabular}{|c|c|c|}
\hline Students & Male Teacher & Female Teacher \\
\hline A & Motivated & Good Managing \\
\hline B & Motivated & Informed \\
\hline C & Correlated with the Topic & Correlated with the Topic \\
\hline D & Good Managing & Motivated \\
\hline $\mathrm{E}$ & Appropriate Technique & Appropriate Technique \\
\hline $\mathrm{F}$ & Appropriate Technique & Good Managing \\
\hline G & Good Preparations & Good Preparations \\
\hline $\mathrm{H}$ & Motivated & Monitored and Stimulated \\
\hline I & Interesting & Monitored and Stimulated \\
\hline J & Monitored and Stimulated & Monitored and Stimulated \\
\hline K & Good Managing & Motivated \\
\hline $\mathrm{L}$ & Good Managing & Motivated \\
\hline M & Good Managing & Good Managing \\
\hline N & Correlated with the Topic & Appropriate Technique \\
\hline 0 & Correlated with the Topic & Good Managing \\
\hline$P$ & Correlated with the Topic & Good Preparations \\
\hline$Q$ & Appropriate Technique & Monitored and Stimulated \\
\hline $\mathrm{R}$ & Appropriate Technique & Monitored and Stimulated \\
\hline S & Interesting & Monitored and Stimulated \\
\hline $\mathrm{T}$ & Interesting & Good Managing \\
\hline U & Interesting & Good Managing \\
\hline V & Interesting & Appropriate Technique \\
\hline W & Good Preparations & Good Managing \\
\hline$x$ & Good Preparations & Good Preparations \\
\hline Y & Good Preparations & Correlated with the Topic \\
\hline Z & Monitored and Stimulated & Correlated with the Topic \\
\hline A1 & Correlated with the Topic & Appropriate Technique \\
\hline A2 & Good Managing & Appropriate Technique \\
\hline A3 & Appropriate Technique & Interesting \\
\hline A4 & Motivated & Interesting \\
\hline A5 & Motivated & Interesting \\
\hline A6 & Interesting & Correlated with the Topic \\
\hline A7 & Monitored and Stimulated & Correlated with the Topic \\
\hline A9 & Good Managing & Appropriate Technique \\
\hline A10 & Good Managing & Appropriate Technique \\
\hline B1 & Good Managing & Interesting \\
\hline B2 & Motivated & Interesting \\
\hline B3 & Interesting & Interesting \\
\hline B4 & Monitored and Stimulated & Correlated with the Topic \\
\hline B5 & Good Managing & Motivated \\
\hline
\end{tabular}




\section{Discussion}

This section presents result of data analysis of interview. From 40 students interviewed and asked obuot their confessions to male and female teachers, can be conclude that the convessions results show variants and different statements. There are 6 male teacher is confessed motivated in teaching where only 2 female teacher get motivation confessed. An addition, about interested point, 7 males got this confession and 6 females have it. Furthermore, 9 males get confessing good managing and onli 7 females get it. In monitoring and stimulating students, 4 males and 3 females find it. About good preparation beforeteaching, 3 male have convessed by students and 3 females get so. Moreover, 5 males and 5 female teacher have confessed by the students with approriate technique in teaching, and the last is correlated to the topic, 2 males and 6 females assumed by the students.

It is also connected what the expert said about confessions. Lassiter (2004) reveals that people confess for tell something and share some informations. They confess it of his/her own free will and tell it honestly when they are asked. People confess because they want to share their story explicitly or to correct a mistake. Usually without asked, they already confess it for their chest, giving a suggestion, and not happy with a certain situation and condition.

\section{Conclusion}

Based on the result, concluding that both male and female get positive confessions. Male teachers get 36 confessions with good managing confessing (9) is the highest. And correlated to the topic is a few (2). Female teachers get 39 confessions with good managing confessing (7) is the highest, and motivated confession only 2 confessing. Lastly, female teachers get higher confession than male teacher toward technique in teaching.

\section{Acknowledgment}

N/A.

\section{References}

Halidasiah. (2016). A Study on Teachers' Technique in Teaching English to Eleventh Year Students of SMA Negeri 1 Walenrang. Unpublished Thesis. Palopo: Departement of English Education FKIP - UNCP.

Harmer, J. (2007). The Practice of English Language Teaching (4th edition). Harlow: Pearson

Hirsch, A. (2007). Confessions and Harmless Error: A New Argument for an Old Approach. Berkeley Journal of Criminal Law.

Lepiyanto, A. (2011). Pembelajaran Aktif, Inovatif, Kreatif, Efektif, dan Menyenangkan. (online). https://duniagil.wordpress.com/2011/03/07/38/. Accessed on August 30th, 2017.

Laksono, B. (2014). Persiapan Guru Sebelum Mengajar.

(online).http://www.budilaksono.com/2014/03/persiapan-guru-sebelum-mengajar.html. Accessed on August 30th, 2017

Lassiter, G. D. (2004). Interrogations, Confessions, and Entrapment. New York: Kluwer Acad. 
Rianto, M. (2006). Pendekatan, Strategi, dan Metode Pembelajaran. Malang: Direktorat Jenderal Peningkatan Mutu Pendidikan dan Tenaga Kependidikan PPPG IPS- PMP Malang.

Shradda. (2013). Confenssion Under Indian Evidence Act. (online). http://www.legalservicesindia.com/article/article/confession-under-indianevidenceact1547-1.html. Accessed on February 15th, 2017.

Slobogin, C. (2007). Lying and Confessing. Texas. Tech Law Review

Sugiyono. (2014). Metode Penelitian Kuantitatif, Kualitatif Dan R\&D. Bandung: Alfabeta

Wilkes, P. (2010). The Art of Confession: Renewing Yourself Through the Practice of Honesty. (online). https://www.amazon.com/gp/product/0761155961. Accessed on February 15th, 2017. 